\title{
POTENTIAL ANTIOXIDANT AND CYTOTOXIC ACTIVITIES OF ARECA NUT (ARECA CATECHU LINN.) EXTRACT IN HUMAN ORAL SQUAMOUS CELL CARCINOMA AND KERATINOCYTE CELLS
}

\author{
LIZA MEUTIA SARI ${ }^{1}$, GUS PERMANA SUBITA ${ }^{2}$, ELZA IBRAHIM AUERKARI ${ }^{3 *}$
}

${ }^{1}$ Department of Oral Medicine, Faculty of Dentistry, Syiah Kuala University, Banda Aceh, Indonesia. ${ }^{2}$ Department of Oral Medicine, Faculty of Dentistry, University of Indonesia, Jakarta, Indonesia. ${ }^{3}$ Department of Oral Biology, Faculty of Dentistry, University of Indonesia, Jakarta, Indonesia. Email: eauerkari@yahoo.com

Received: 25 May 2017, Revised and Accepted: 01 July 2017

ABSTRACT

Objectives: Areca (betel, Areca catechu) nuts have been reported to show high contents of phenolic and flavonoid compounds with associated antioxidant activity. This study was undertaken to assess the anticancer potential of areca nut extract on human squamous carcinoma (HSC)-3, HSC-2, and human keratinocyte (HaCat) cancer cell lines, and to elucidate the mechanism of its action.

Methods: In this study, the areca nut extract was prepared in 96\% ethanol and analyzed for the total phenolic and flavonoid content, 2,2-diphenyl-1picrylhydrazyl (DPPH) assay, and 5-(3-carboxymethoxyphenyl)-2-(4,5-dimenthylthiazoly)-3-(4-sulfophenyl)tetrazolium inner salt assay.

Results: The indicated total phenolic content of the areca nut extract was $80.3 \mathrm{mg}$ tannic acid equivalent/g and total flavonoid content $238.5 \mathrm{mg}$ catechin equivalent/g. The extract showed good scavenging activity against DPPH radical (efficient concentration $15.95 \pm 0.84 \mu \mathrm{g} / \mathrm{ml}$ ). The extract showed higher toxicity on HSC-3 than HSC-2 cells, $\mathrm{IC}_{50}$ was $164.06 \mu \mathrm{g} / \mathrm{ml}$ in HSC-3 versus $629.50 \mu \mathrm{g} / \mathrm{ml}$ in HSC-2. The extract had no cytotoxic effect on HaCat cells.

Conclusions: The antioxidant activity of the areca nut extract might be associated with the presence of high content of phenolic and flavonoid compounds. The extract showed selective cytotoxicity against HSC-3 and HSC-2 cells but not on HaCat cells. Instead, the extract induced high rate of proliferation in HaCat cells.

Keywords: Areca nut, Antioxidant, Cytotoxicity, Oral cancer.

(c) 2017 The Authors. Published by Innovare Academic Sciences Pvt Ltd. This is an open access article under the CC BY license (http://creativecommons. org/licenses/by/4. 0/) DOI: http://dx.doi.org/10.22159/ajpcr.2017.v10i10.20287

\section{INTRODUCTION}

Oral squamous cell carcinoma (OSCC) covers more than $90 \%$ of all cases of oral cancer and ranks fifth in cancer incidence in the world [1]. In terms of geography, 3-6\% of the cases of squamous cell carcinoma occur in western countries, while the rate is up to $30 \%$ in the East, including Indonesia [2]. The 5-year survival rate for this type of cancer remains relatively low and has not changed much for the past 40 years $[3,4]$. The current standard therapies are surgery, radiotherapy, and chemotherapy. The recurrence rates are proved to be lower, but there are several side effects from the treatment that cause serious morbidity especially at the late stage of OSCC. The side effects of current chemotherapy are increased toxicity, reduced immune status, and oral disorders such as xerostomia, mucositis, and osteoradionecrosis [5]. This day, people tend to use back-to-nature lifestyle using herbs because of the concern of unwanted side effects of synthetic medicines. To find useful new sources of cancer drugs, large numbers of species of plants, animals, and microorganisms are screened in the hope to discover fresh potential for anticancer properties [6].

The reason for using plants as medicine lies in the fact that they contain chemical components of therapeutic value [7]. One of the plants with a potential to be developed as herbal medicine is the Pinang plant (Areca catechu Linn.; areca, Palmaceae). Areca nut is traditional herbal medicine that is popular around India, Thailand, and Taiwan. This plant spreads widely in South East Asia, South Africa, and Pacific Ocean Islands. It is usually used in betel chewing common among the Indians and Malays as breath freshener, digestive aid, worm expellant, aphrodisiac, and to maintain stamina [8]. Several studied functions of areca plant showed that the stem can be used as antibacterial and antifungal agent [9]. The seeds can be used as antioxidant, antiaging, antihelmintic, antimicrobial, analgesic, and anti-inflammatory [9-13].

Epidemiologic study and laboratory research found large amount of anticancer compounds obtained from fruits or plants. Some of them contained flavonoid and polyphenol, carotenoid, selenium, Vitamin C and $\mathrm{E}$ which showed chemotherapy and preventive activity. Antioxidant is one of the solutions to minimize oxidative stress level caused by cancer treatment. Antioxidant is a compound that is capable to cleanse, dispose, and repel free radical or reactive oxygen species forming in the body [14]. The previous study showed that methanol and water extract of areca nut contains tannin and high total phenolic [15]. Besides phenolic compound, areca nut also contained flavonoid, syringic acid, procyanidin, and epicatechin $[16,17]$. This compound has stronger free radical scavenging activity than ascorbic [18]. The flavonoid compound in areca nut has strong cytotoxicity activity in human gastric cancer cell line (SGC-7901) and human liver cancer cell line (SMCC-7721) [18], but the molecular mechanism of areca nut cytotoxicity against human squamous carcinoma (HSC) and normal cells is not fully understood. The objective of this study was to evaluate the potency of the antioxidant components from the areca nut for inducing cytotoxicity of HSC and human keratinocyte (HaCat) cell lines as an effort to develop a new active substance for natural antioxidant herbal medicine.

\section{METHODS}

Sample material

The areca plant material for the study was obtained from betel nuts of A. catechu (Pinang) plants from Aceh Besar, Indonesia, identified and documented by the Botanical Division of Biological Research Center of 
LIPI Cibinong, complete with roots, stems, leaves, flowers, and seeds in 2015 .

\section{Extraction}

The sample used was $2 \mathrm{~kg}$ of areca nut (gross weight). Areca nut was collected and cleansed from dirt (wet sortation), then washed with running water until clean and drained. Those seeds were dried in open air and covered from direct sunlight then continued with drying using oven at $50^{\circ} \mathrm{C}$. Dried simplicia was crushed using blender so it became powdered simplicia and sifted with 20 mesh sieve. The powder was macerated with $96 \%$ ethanol solvent. Around 500 g powdered simplicia was put into container then poured with $96 \%$ ethanol, closed and left for 3 days covered from sunlight, while repeatedly stirred. After 3 days, the extract was strained, the left extract was dried. The dried extract was added 96\% ethanol and stirred, after acquiring all extract. The container was closed, left in cool place and covered from sunlight for 2 days. The sediment was separated and liquid extract was obtained. After that, the extract was evaporated using rotary evaporator at 30$40^{\circ} \mathrm{C}$ then concentrated again using water bath so dense extract of areca nut would be obtained.

\section{Analysis of total phenolic content}

The total phenolic content of the extract was determined by the Folin-Ciocalteu method with some modifications [19]. Methanolic solution of the extract in the concentration $0.1 \mathrm{mg} / \mathrm{mL}$ was used in the analysis. The reaction mixture was prepared by mixing $0.5 \mathrm{~mL}$ solution of extract, $2.5 \mathrm{~mL}$ of $10 \%$ Folin-Ciocalteu reagent dissolved in water and $2.5 \mathrm{~mL}$ of $7.5 \% \mathrm{Na}_{2} \mathrm{CO}_{3}$. Blank was concomitantly prepared, containing $0.5 \mathrm{~mL}$ methanol, $2.5 \mathrm{~mL}$ of $10 \%$ Folin-Ciocalteu reagent dissolved in water, and $2.5 \mathrm{ml}$ of $7.5 \%$ of $\mathrm{Na}_{2} \mathrm{CO}_{3}$. The standard solutions were $0.0025,0.005,0.01,0.02$, and $0.04 \mathrm{mg} / \mathrm{mL}$. The extract sample, blank, and standard solution were there after incubated in a thermostat at $45^{\circ} \mathrm{C}$ for 30 minutes. The absorbance was determined using UV-Vis mini 1240 spectrophotometer at $765 \mathrm{~nm}$. The samples were prepared in triplicate for each analysis, and the mean value of absorbance was obtained. The same procedure was repeated for the standard solution of tannic acid and the calibration line was constructed. Based on the measured absorbance, the concentration of phenolics was read $(\mathrm{mg} / \mathrm{mL})$ from the calibration line; then the content of phenolic in extracts was expressed in terms of tannic acid equivalent (mg of TAE/g of extract).

\section{Analysis of total flavonoid content}

The total flavonoid content was determined using the Dowd method with some modifications [20]. $2.5 \mathrm{~mL}$ of $2 \%$ aluminum trichloride $\left(\mathrm{AlCl}_{3}\right)$ in methanol was mixed with the same volume of the extract solution $(0.1 \mathrm{mg} / \mathrm{mL})$. A blank sample was consisted of $2.5 \mathrm{~mL}$ extract solution with methanol without $\mathrm{AlCl}_{3}$. Standard was consisted of $2.5 \mathrm{~mL}$ catechin standard with $2.5 \mathrm{~mL}$ of $2 \% \mathrm{AlCl}_{3}$ in doses of 3.75 , 15 , and $30 \mu \mathrm{g} / \mathrm{mL}$. Absorption readings at $415 \mathrm{~nm}$ using UV-Vis mini 1240 spectrophotometer were taken after 10 minutes against a blank sample. The total flavonoid content was determined using a standard curve with catechin $(0-100 \mathrm{mg} / \mathrm{mL})$ as the standard. Total flavonoid content is expressed as mg of catechin equivalents (CE)/g of extract.

\section{2,2-diphenyl-1-picrylhydrazyl (DPPH) radical scavenging activity}

The DPPH free radical method is based on the determination of the concentration of DPPH at steady state in an ethanol solution, after adding the mixture of antioxidant. The DPPH absorbs at $515 \mathrm{~nm}$, and as its concentration is reduced by the existence of an antioxidant, the absorption gradually disappears with time. A Perkin Elmer UVVIS Lambda 25 spectrophotometer was used and the quantity of the mixture of antioxidants needed to reduce by $50 \%$ the initial DPPH concentration was evaluated. Butylated hydroxy toluene (BHT) was used as a positive control, while the DPPH-ethanol mixture without the extract was used as the blank control. The percentage inhibition of DPPH radical was calculated using the following formula:

$$
\text { Inhibition percentage }=\frac{\left(\mathrm{A}_{\text {blank control }}-\mathrm{A}_{\text {sample }}\right)}{\mathrm{A}_{\text {blank control }}} \times 100
$$

This characteristic parameter is called efficient concentration $\left(\mathrm{EC}_{50}\right)$ or oxidation index. The lower the $\mathrm{EC}_{50}$, higher is the antioxidant activity of the examined compound. This assay used various concentration of areca nut extract $(1,2,5,10$, and $20 \mu \mathrm{g} / \mathrm{mL})$. In this assay, dry areca nut extract $0.3 \mathrm{mg}$ was mixed with $2.7 \mathrm{ml} 70 \%$ ethanol solution containing $40 \mu \mathrm{g} / \mathrm{mL}$ DPPH radical (Sigma chemical company, St. Louis, MO, USA) [21]. This mixed solution is whisked and left for 60 minutes in dark room so that stable absorbance value could be achieved.

\section{Cell culture}

The HSC-2, HSC-3, and HaCat cell lines were cultured in complete Dulbecco's modified Eagle's medium containing 10\% fetal bovine serum, nonessential amino acids, pyruvate, glutamine, and vitamins at $37^{\circ} \mathrm{C}$ in a $\mathrm{CO}_{2}$ incubator. All media were also supplemented with 100 units/mL of penicillin and $100 \mathrm{mg} / \mathrm{mL}$ of streptomycin. The abovementioned cell lines were procured more than 6 months ago and have not been tested recently for authentication in our laboratory. The HSC3, HSC-2, and HaCat cell lines used in this study were provided by the Oral Biological Laboratory, Faculty of Dentistry, Indonesia University. The HSC-3 cell line was derived from an OSCC of the tongue with a p53 gene mutation, namely, a $4 \mathrm{bp}$ insertion or change in amino acid in the form of TAAG insertion in codon 305-306, exon 8 [22]. The HSC-2 cell line was also derived from an OSCC of the tongue but without the p53 gene mutation [23]. The HaCat cell line was a dermal keratinocyte line, a spontaneous or natural immortalized aneuploidy without exogenic oncogenic influence or gene mitosis, and was nontumorigenic [24].

Cell lines, placed in cryophilic liquid $\mathrm{N}_{2}$, were then moved into $15 \mathrm{ml}$ tube, then phosphate-buffered saline (PBS) was added until $10 \mathrm{ml}$. The thawing process started with centrifuge at $500 \mathrm{rpm}$ for 10 minutes, the supernatant was disposed, the cell concentrate at the base of the tube (pellet) was added with 2-3 ml complete Dulbecco's modified Eagle's medium (DMEM), and then it was pipetted to culture plat containing 7-10 ml DMEM medium and was spread evenly. It was incubated in $\mathrm{CO}_{2}$ incubator with temperature $37^{\circ} \mathrm{C}$. The conversion of medium was started by disposing old medium from culture plat by pipetting, rinsing with PBS 2-3 times to the whole surface of the plat, pouring new complete DMEM medium around seven to ten $\mathrm{ml}$ then it was placed again into the incubator. If the cell achieved $80 \%$ confluents, then the confluents was ready to be harvested. The medium was disposed and rinsed with PBS $\mathrm{NO} \mathrm{Ca}_{2}$ and $\mathrm{NO} \mathrm{Mg}_{2}$ two to three times with volume of $2 \mathrm{ml}$, then $1 \mathrm{ml}$ Trypsin EDTA was added, then it was incubated for 5-10 minutes. The addition of complete DMEM for 2 to $3 \mathrm{ml}$ and then moved into $15 \mathrm{ml}$ tube by pipetting, centrifuge at $500 \mathrm{rpm}$ for 10 minutes, the supernatant was disposed. The pellet was homogenized by pipetting. The resuspended cell with this culture medium was ready to be used for experiment, and cell count with hemocytometer was performed. The observation of morphology of the grown cell with/without treatment was performed with inverted microscope and photographs.

\section{5-(3-carboxymethoxyphenyl)-2-(4,5-dimenthylthiazoly)-3-(4-} sulfophenyl)tetrazolium inner salt (MTS) assay

MTS assay was performed to observe the cytotoxicity effect of areca nut extract at five doses which were $160,320,640,1280$, and $2560 \mu \mathrm{g} / \mathrm{mL}$ at HSC-3, HSC-2, and HaCat cells. On reaching confluence, the cell culture was harvested and counted using hemocytometer to obtain the concentration of $2 \times 10^{4}$ cells $/ 100 \mu \mathrm{L}$, then transferred into 96-well plate-flat bottom well, and placed in the incubator for $2 \mathrm{hrs}$. The MTS reagent (CellTiter $96^{\circledR}$ AQueous One Solution Reagent) was thawed at room temperature after 90 minutes or 10 minutes in water bath at $37^{\circ} \mathrm{C}$. The MTS reagent was then mixed with a PMS solution, an electron coupling reagent using a ratio of 20:1, and the mixture was set aside for $2 \mathrm{hrs}$. A $20 \mu \mathrm{l}$ digital pipette was used to transfer the MTS reagent into each well in the 96 -well plate-flat bottom well containing $2 \times 10^{4}$ cells $/ 100 \mu \mathrm{L}$ in culture medium. Plate was incubated for $1-4 \mathrm{hrs}$ at $37^{\circ} \mathrm{C}$ in a $5 \% \mathrm{CO}_{2}$ incubator. The absorbency was recorded using a spectrophotometer at $490 \mathrm{~nm}$ wavelength using a microplate reader (Multiskan Go, USA). All tests were performed in triple. 
Statistical analysis

All data were presented as the mean \pm standard deviation of triplicate parallel measurements. Statistical analysis used the MS Excel software to calculate BHT, catechin and tannic acid equivalent, MTS assay, to determine inhibition of percentage and to establish linear regression equations.

\section{RESULTS}

\section{Total phenolic content}

Absorbance data of spectrophotometric showed the formula of standard phenolic curve $\mathrm{y}=4.807 \mathrm{x}-0.0038$, with $\mathrm{R}^{2}$ value $99.99 \%$ (Fig. 1). The value of total phenolic concentration in 1 gram extract is $80.3 \mathrm{mg}$ TAE$/ \mathrm{g}$ extract. The highest phenolic concentration was usually found in methanol, acetonide, and water solvent. This concentration is depended on how big the solvent's polarity used at extraction. The high phenolic solubility in polar solvent showed high concentration of phenolic content in the extract.

\section{Total flavonoid content}

The total flavonoid content in the extract was measured using catechin as standard. The result shows the formula of standard flavonoid curve $y=0.0008 x+0.0467$, with $R^{2}$ value $96.50 \%$ (Fig. 2). The value of total flavonoid concentration in $1 \mathrm{~g}$ extract is $238.5 \mathrm{mg} \mathrm{CE} / \mathrm{g}$ extract.

\section{DPPH radical scavenging activity}

The result of DPPH test analysis showed $\mathrm{EC}_{50}$ extract in $96 \%$ ethanol solvent was $15.95 \pm 0.84 \mu \mathrm{g} / \mathrm{mL}$, and in BHT was $32.86 \pm 1.49 \mu \mathrm{g} / \mathrm{mL}$. This result showed the effective concentration of areca nut extract needed to scavenge $50 \%$ free radical in the sample was $15.95 \mu \mathrm{g} / \mathrm{mL}$, while BHT needed twice as much concentration of areca nut extract. The comparative curve between antioxidant activity of extract and BHT was shown in Fig. 3. The strength of scavenging capacity of areca nut extract is associated with the large amount of total phenolic and flavonoid which acted as hydrogen antioxidant donor.

\section{Cytotoxicity effect of areca nut extract is stronger in HSC-3 cells} compared to HSC-2 cells

Preliminary study had been performed using extracts in doses of 10, 20, $40,40,60$, and $80 \mu \mathrm{g} / \mathrm{mL}$ in both types of the cell lines, but $\mathrm{IC}_{50}$ value was not found because the extract was not capable to inhibit growth in $50 \%$ of all cells. MTS assay was repeated to observe the cytotoxicity effect of areca nut extract in higher five doses, which were 160, 320, 640, 1280, and 2560 $\mu \mathrm{g} / \mathrm{mL}$ in HSC-2, HSC-3, and HaCat cells. Cytotoxicity of the extract was displayed with viability percentage. With higher extract concentration, the viability percentage occurred would be lower. The result showed

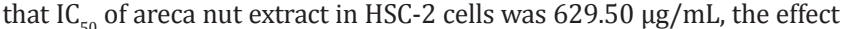
started at concentration $320 \mu \mathrm{g} / \mathrm{mL}$. The $\mathrm{IC}_{50}$ value in HSC-3 occurred in low concentration which was $164.06 \mu \mathrm{g} / \mathrm{mL}$. Cytotoxicity effect started from smallest concentration which was between 160-640 $\mu \mathrm{g} / \mathrm{mL}$, but at concentration higher than $1280 \mu \mathrm{g} / \mathrm{mL}$, the extract started to show proliferative activity. Areca nut extract provided stronger cytotoxicity effect in HSC-3 cells than in HSC-2 cells. The cytotoxicity graph of the three cell lines is shown in Fig. 4.

\section{No cytotoxicity effect of areca nut extract in HaCat cells}

This study was also performed in HaCat cell lines to observe whether the extract was cytotoxic to normal cell lines or not. HaCat cells were given the same treatment as OSCC cell lines. The result showed that areca nut extract did not develop cytotoxicity to HaCat cells. Proliferative activity occurred in more than $100 \%$ cell viability, starting from smallest concentration $(160 \mu \mathrm{g} / \mathrm{mL})$ and increasing as the number of extract concentration increased. The increased proliferation percentage for the first time was 15 times fold than control cell $100 \%$ viability, after that the number of cells kept increasing gradually (Fig. 4). This study was not able to determine the $\mathrm{IC}_{50}$ value because there was no cell death up to $50 \%$ from total living cells. Viability assay in HaCat cells showed that areca nut extract was relatively safe if used on normal cells not cancer cells, so this material could potentially reduce the side effects of chemoradiotherapy.

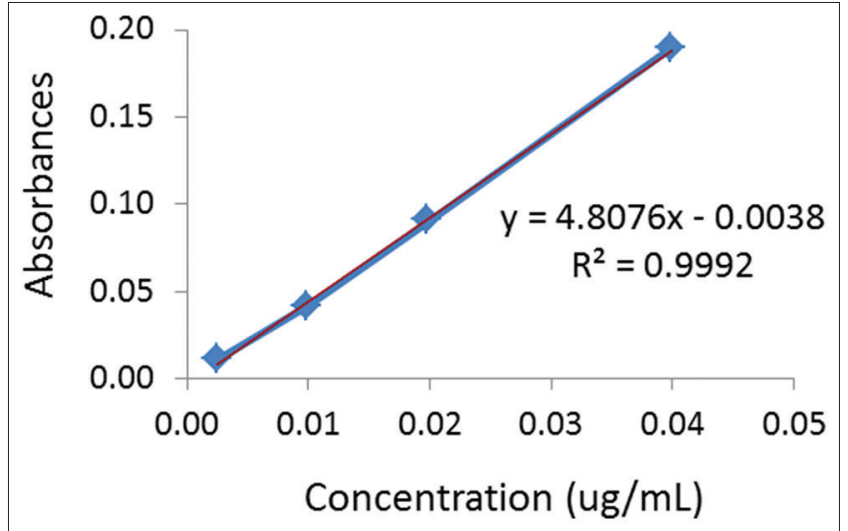

Fig. 1. Total phenolic content

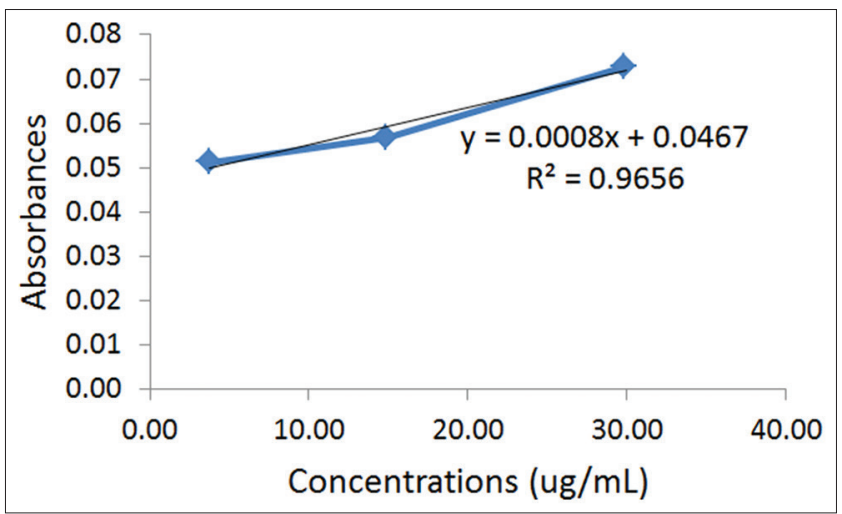

Fig. 2: Total flavonoid content

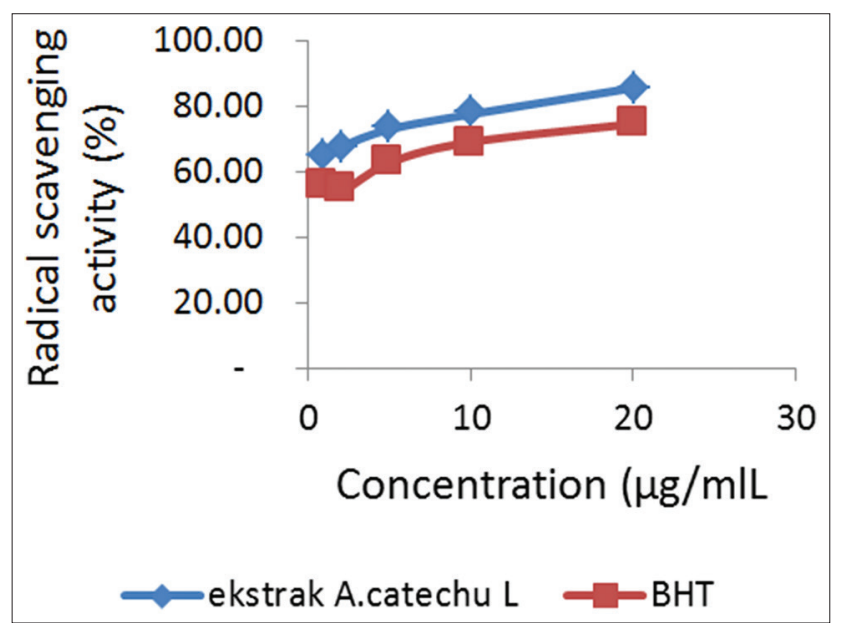

Fig. 3. Antioxidant activity estimated by 2,2-diphenyl-1picrylhydrazyl method. Linear curve of areca nut extract has similar linearity with butylated hydroxy toluene control. The dosage used was $1-20 \mu \mathrm{g} / \mathrm{mL}$

\section{DISCUSSION}

The majority of community prefer to choose herbal medicine because natural ingredient is considered to be safer and cheaper than chemical drugs. The precipitating factors of increasing use of herbal medicine in developed countries are the side effects of chemical drugs, the high cost of modern medicine, and the increasing life expectancy when prevalence of chronic disease had increased, so herbal medicine becomes alternative treatment that is believed to cover all classes of community especially in Indonesia [25]. In Taiwan and South-Eastern 


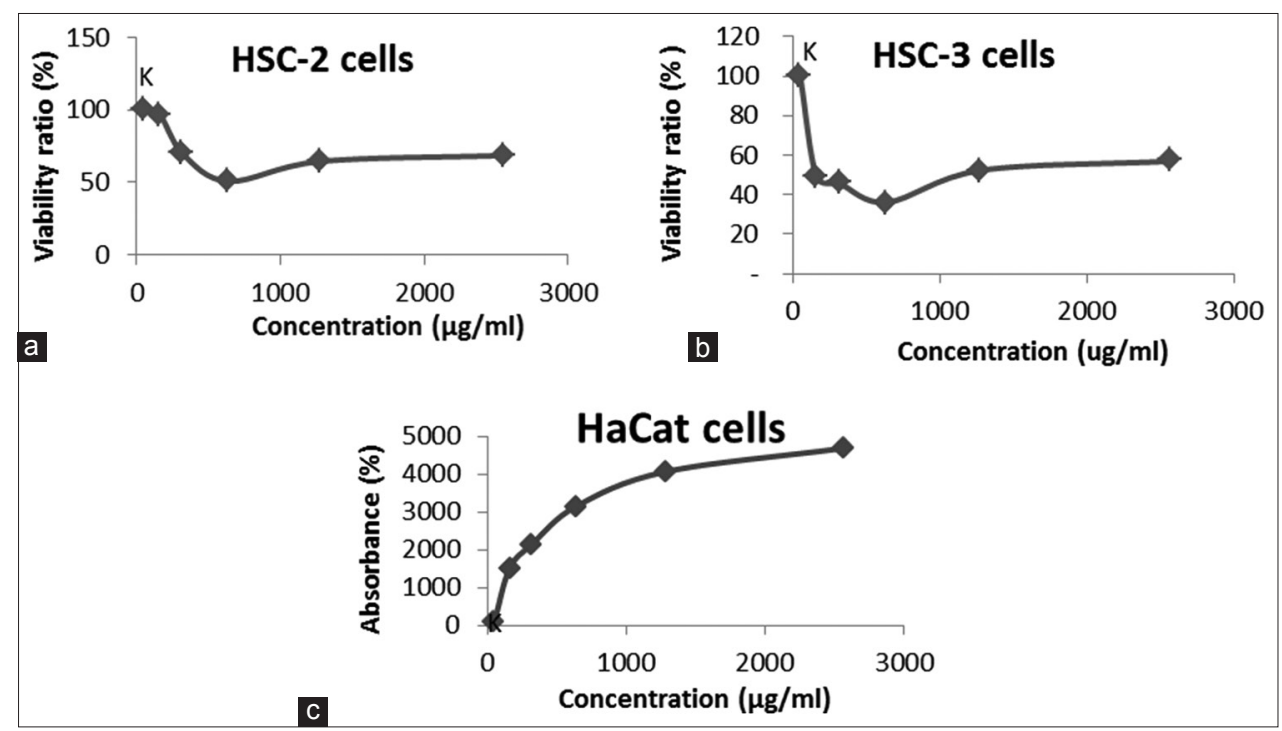

Fig. 4: The result of 5-(3-carboxymethoxyphenyl)-2-(4,5-dimenthylthiazoly)-3-(4-sulfophenyl)tetrazolium inner salt assay in human squamous carcinoma (HSC)-2, HSC-3, and human keratinocyte (HaCat) cell lines. Areca nut extract has stronger cytotoxicity effect in HSC-3 (b) than in HSC-2 (a), the proliferative effect occurs at certain concentration in the two cell lines but does not pass $100 \%$ cell viability. The extract has not shown cytotoxicity effect in HaCat cells (c)

Asia, areca nut chewing has been associated with the development of OSCC through epidemiological studies and has been classified as a human carcinogen by the IARC (2004) [17]

Actually, areca nut does not contain carcinogenic substance, but this carcinogenic effect is caused by nitrosamines product in long term and uncontrollable. Nitrosamines are produced by nitrosation of the alkaloids in dried stored nuts, when in the mouth, and especially in the acid conditions of the stomach, in the presence of nitric oxide generated by bacteria [26]. The combination with nitric oxide, produced by bacteria, causes the production of methylnitrosaminoproprionitrile which is proved to cause carcinogenesis in animal studies [26]. This endogen nitrosation is higher significantly in patient with bad oral hygiene [27]. If areca nut is combined with tobacco, then chewed by people with bad oral hygiene, there will be very high accumulation of nitrosamines product [28]. This process usually occurs continuously for long term because the seeds have addictive property. Some studies also reported increased reactive oxygen species such as hydroxyl oxide in oral cavity caused by combination of polyphenol autooxidation from areca nut with high alkaline $\mathrm{pH}$ of slaked lime (calcium hydroxide paste) [29]. If areca nut is chewed with piper betel and slaked lime, these two materials will cause mucous membrane erosion so that carcinogenic substance could easily penetrate cells through mucous membrane [30]. Some part of community in India and Pakistan use industrial packaging areca nut called gutka and pan masala. Gutka contains areca nut, piper betel, tobacco, and slaked lime, while pan masala was prepared without tobacco. Approximately, $40 \%$ of gutka and pan masala packaging are contaminated with aflatoxin which has carcinogenic property from Aspergillus flavus, Aspergillus niger, and Rhizopus spp. fungi [31]. The occurrence of the OSCC's risk depends greatly on the composition of the compound which determines the quality of the seeds, the method of using seeds which is associated with oral hygiene, duration of use, the presence or absence of toxin caused by fungi contamination in the seeds, and the presence or absence of other carcinogenic substances such as tobacco and slaked lime. The occurrence of OSCC could also be influenced by several factors such as intrinsic factors (tumor suppressor gene abnormality or mutation and oncogene) and extrinsic factors (tobacco smoking, vitamin A and iron deficiency, candidiasis, viral infection, and immunosuppression) [5].

This study proved that the phytochemistry of areca nut has antioxidant activity. Total phenolic content test using Folin-Ciocalteu method was performed based on oxidation-reduction mechanism. Methanol is the best solvent for areca nut compared to petroleum ether, ethyl acetate, and water, and was used in this study [32]. Tannin is a phenylpropanoid compound with large molecular weight formed in the polymerization of catechin (a family of polyphenol). When compared with literatures using the same method, the phenolic content of areca nut in this study is lower than that of a study conducted in Assam, India (146.7 mg TAE/g extract) and Hainan province, Taiwan (167.70 mg TAE/g extract) [16,32]. Total flavonoid test using Dowd modification method also revealed a higher content of flavonoid (238.5 mg CE mg/gr extract). This number is higher than that reported by Zhang et al. (2011) and Wang et al. (1998), which was 77.36 and 10.45-142.65 mg CE mg/gr extract, respectively. This indicates that the variation of polyphenol content depends on the geographical locations where the plant grows. This variation is also affected by species and the characteristics of nut used in the study, including freshness, maturity, and methods of drying.

DPPH is a stable nitrogen-centered free radical, the color of which changes from violet to yellow on reduction by either the process of hydrogen- or electron-donation. Substance which is able to perform this reaction can be considered as antioxidants and therefore radical scavengers [19]. DPPH test is a direct and reliable method for determining radical scavenging action. The reducing properties are generally associated with the presence of reductones, which have been shown to exert antioxidant action by breaking the free radical chain by donating a hydrogen atom. The result of antioxidant activity curve showed linear line formula so $\mathrm{EC}_{50}$ value was acquired. $\mathrm{EC}_{50}$ value is the extract concentration which was able to catch $50 \%$ free radical. The $\mathrm{EC}_{50}$ value was measured from association curve between the percentages of radical catcher DPPH against the concentration of treatment's solution. This value is inversely proportional with antioxidant extract capability. The higher antioxidant activity, the lower $\mathrm{EC}_{50}$ would be. The study showed that the $\mathrm{EC}_{50}$ value was $15.95 \mu \mathrm{g} / \mathrm{mL}$. The polyphenol could dispose free radical by becoming hydrogen donor so the free radical chain reaction was broken. The $\mathrm{EC}_{50}$ value of the extract was smaller than BHT (synthetic antioxidant posing as control). The result of the study showed stronger antioxidant activity of areca nut compared to BHT control, so it could be concluded that the activity potency of a combination of several phenolic compounds in the extract could work synergically and resulted in more potent antioxidant than activity of one isolate in the extract [20]. Polyphenol had stimulation effect on mitochondria's activity, so it could be more efficient in creating 
energy and preventing free radical. This also explained the increased cell viability graph over $100 \%$ in HaCat cell line. This was possibly caused by the high extracellular formazan intensity from tetrazolium salts reduction by dehydrogenase succinate enzyme which performs respiration and metabolism. The more energy and cellular respiration result, the more formazan would be formed.

MTS assay showed increased cellular viability in doses higher than $\mathrm{IC}_{50}$, which was $16.2 \%$ followed by $4.5 \%$ in HSC-3 cells and an increase of $13.8 \%$ and $4 \%$ in HSC-2 cells. This was caused by strong antioxidant activity in the extract. Polyphenol had direct stimulation effect on mitochondria's activity, so it was more efficient in producing energy and free radical scavenging. This was probably caused by the high extracellular formazan intensity from tetrazolium reduction by dehydrogenase succinate enzyme in cells performing respiration and metabolism. The more energy and cellular respiration product, the more formazan would be formed. Areca nut extract did not cause cytotoxicity in HaCat cell lines. This study showed that areca nut could induce formazan in large number, so it showed large increase in cell number. This was not caused by the high HaCat cells viability, but because of the high absorbance value in accordance with the dense of formazan color which was influenced by cellular respiration and metabolism. This absorbance value was read based on $490 \mathrm{~nm}$ wavelength. The denser the color of formazan's product, the higher the absorbance value would be. Although this study did not perform the test for nicotinamide adenosine dinucleotide hydrogen (NADH) content in the extract but it is possible that areca nut extract contains NADH which could provide additional energy for the cells. NADH is active coenzyme form of vitamin B3 (Niacin) which has important role in nervous system. This vitamin is found in all living cells of plant, animal and human. Tharakan et al. (2005) showed that Trichopus zeylanicus containing NADH had antioxidant activity by inducing lipid peroxidase and inhibiting lipoxygenase activity [33]. Further studies are needed to detect NADH content in areca nut.

Flavonoid in areca nut extract has antioxidant and also pro-oxidant activity. These two activities were also possessed by other herbal plants and curcumin $[34,35]$. Lower dose of curcumin $(12.5 \mu \mathrm{M})$ has the properties of reactive oxygen species scavenging, anti-inflammatory, apoptosis induction, and proliferation inhibition in myeloid leukemic cells, but in higher dose and long term, the metabolite contents of curcumin, which is lipophilic or water insoluble, could increase the level of cellular reactive oxygen species that causes carcinogenic potential through oxidative DNA damage or metal-mediated DNA damage at P450 cytochrome [36,37]. This damage occurred because of the presence of $\mathrm{Cu}(\mathrm{II})-\mathrm{CYP} 2 \mathrm{D} 6$ which caused the damage of the DNA, especially 5-TG-3, 5-GC-3, and GG sequences [36]. Curcumin could induce lung cancer by increasing reactive oxygen species resulting in disarray between mitogen-activated protein kinase, NF-jb, and p53, causing genetic mutation and oxidative stress [38]. This finding concluded that the antioxidant effect which was started by oxidative stimulus, depending on time, dose and certain cancer type, could also cause unwanted side effects [38].

The principle of MTS assay method was determined by reductionoxidation reaction occurring in cells. MTT/MTS reagent was reduced into formazan salts by succinate dehydrogenase enzyme found in living mitochondria cells [39]. This reaction was allowed to take place for $4 \mathrm{hrs}$ then stopper reagent was added in MTT assay [40]. The stopper reagent will lysate the cell's membrane so that formazan salts could get outside of the cell and it could be dissolved. The MTS assay did not need stopper reagent because formazan could dissolve in culture medium with addition of PMS $[39,41]$. The formazan salt, which was in extracellular, was quantified with spectrophotometer and measured in the form of absorbance. The higher the absorbance, the higher cell viability would be [41]. The $\mathrm{IC}_{50}$ value between $\mathrm{HSC}-2$ and HSC-3 cells had quite large difference range. This difference showed the selective toxicity difference and type of cell death in some OSCC cell lines during exposure by natural anticancer or synthetic agent.
The flavonoid compound showed weak cytotoxicity activity against HSC-2 cells so the $\mathrm{IC}_{50}$ value was higher $[23,42]$. The factors of the substance in plants that influenced the cytotoxicity capability was the presence or absence of hydrophilic and hydrophobic groups in one same molecules, the presence or absence of isoprenyl groups, the presence or absence of polycyclic and/or halogen structure, the most condensed structure (low molecular weight is more cytotoxic) and lipophilicity. The factors from inside the cells which could probably cause this cytotoxicity were the difference of protein expression which was resistant against some anticancer agent and expression of drug's metabolism enzyme or natural substances [42]. Environmental factors were serum type, the presence of metal ion, oxygen concentration and external pressure [42]. The success of MTS assay depended greatly on cell's metabolism and respiration capability. This study also showed the morphology of HSC-2 cells which was different with HSC-3 cells. The HSC-2 cells had bigger, wider cytoplasm and tighter cell junction than HSC-3 cells that probably could cause weaker extract's cytotoxicity activity than in HSC-2 cells so the $\mathrm{IC}_{50}$ value of $\mathrm{HSC}-2$ was higher than HSC-3 cells.

Areca nut extract did not cause cytotoxicity in normal cells. This was proven by the proliferative activity in more than $100 \%$ HaCat cells' number so that the $\mathrm{IC}_{50}$ value could not be determined. This study showed that areca nut could induce high number of formazan formation, so it showed high increase in cell number. This occurred not because of the high HaCat cell viability, but because of the high absorbance value in accordance with the dense color of formazan influenced by cell's metabolism and respiration. This absorbance value was measured in $490 \mathrm{~nm}$ wavelength. The denser the color of formazan product, the higher the absorbance value would be. Although this study did not perform a test for NADH content in the extract, it is possible that areca nut extract contains NADH which could provide additional energy for the cells. NADH is active coenzyme of vitamin B3 (Niacin) which has an important role in nervous system. This vitamin is found in all living cells of plant, animal and human. Other herbal plants that contain NADH is T. zeylanicus. Tharakan et al. showed that T. zeylanicus had antioxidant activity by inducing lipid peroxidase and inhibiting lipoxygenase activity [33]. This plant also contains NADH, polyphenol, and sulfydryl compound that provide scavenging activity against reactive oxygen species [33]. Further studies are needed to detect NADH content in areca nut.

\section{CONCLUSION}

In conclusion, studies of the chemical constituents from areca nut have an influence in radical scavenging and cytotoxicity activity of the extracts. The results clearly indicate that Areca nut extract had high contents of phenols and flavonoids and high related antioxidant activity. These studies indicate that this nut is a significant source of natural antioxidant. Isolation and characterization of compound rich in phenolic and flavonoid from the nut may lead to the discovery of new antioxidant compound. The extract was cytotoxic toward HSC-2 and HSC-3 but not on HaCat cells. The areca nut extract could be used as alternative sources of antioxidant for therapeutic purposes in oral health care.

\section{REFERENCES}

1. Khan MA, Saleem S, Shahid SM, Hameed A, Qureshi NR, Abassi Z, et al. Prevalence of oral squamous cell carcinoma (OSCC) in relation to different chewing habits in Karachi. Pak J Biochem Mol Biol 2012;45(2):59-63.

2. Ascani G, Balercia P, Messi M, Lupi L, Goteri G, Filosa A, et al. Angiogenesis in oral squamous cell carcinoma. Acta Otorhinolaryngol Ital 2005;25(1):13-7.

3. Jemal A, Siegel R, Ward E, Hao Y, Xu J, Murray T, et al. Cancer statistics, 2008. CA Cancer J Clin 2008;58(2):71-96.

4. Siegel RL, Miller KD, Jemal A. Cancer statistics, 2015. CA Cancer J Clin 2015;65(1):5-29.

5. Neville BW, Damm DD, Allen CM, dan Bouquot JE. Squamous Cell Carcinoma in Oral and Maxillofacial Pathology. $2^{\text {nd }}$ ed. Philadelphia, PA, Pennsylvania: Saunders; 2002. 
6. Sreejamole KL, Radhakrishnan CK. Antioxidant and cytotoxic activities of ethyl acetat extract of the Indian green Perna viridis. Asian J Pharm Clin Res 2013;6(3):197-201

7. Chitra T, Jayashree S, Rathinamala J. Evaluation of anticancer of Vetiveria zizanioides against breast cancer cell line. Int J Pharm Pharm Sci 2014;6(1):164-6.

8. Hamsar MN, Ismail S, Mordi M, Ramanathan S, Mansor SM. Antioxidant capacity and the effect of different parts of Areca catechu extracts on gluthatione-S-transferase activity in vitro. Free Radic Antioxid 2011;1(1):28-33

9. Jaiswal P, Kumar P, Singh VK, Singh DK. Areca catechu L.: A valuable herbal medicine againts different health problems. Res J Med Plant 2011;5(2):145-52.

10. Kim BJ, Kim JH, Kim HP, Heo MY. Biological screening of 100 plant extracts for cosmetic use (II): Anti-oxidative activity and free radical scavenging activity. Int J Cosmet Sci 1997;19:299-307.

11. Lee KK, Choi JD. The effects of Areca catechu L extract on antiinflammation and antimelanogenesis. Int J Cosmet Sci 1999;21(4):27580 .

12. Lee KK, Choi JD. The effects of Areca catechu L extract on anti-aging. Int J Cosmet Sci 1999;21(4):285-95.

13. Bhandare AM, Kshirsagar AD, Vyawahare NS, Hadambar AA, Thorve VS. Potential analgesic, anti-inflammatory and antioxidant activities of hydroalcoholic extract of Areca catechu L. nut. Food Chem Toxicol 2010;48(12):3412-7.

14. Velioglu YS, Mazza G, Gao L, Oomah BD. Antioxidant activity and total phenolics in selected fruits, vegetables, and grain products. J Agric Food Chem 1998;46(9):4113-7.

15. Ahsan H, Ali A, Ali R. Oxygen free radicals and systemic autoimmunity. Clin Exp Immunol 2003;131(3):398-404.

16. Zhang WM, Wei J, Chen WX, Zhang HD. The chemical composition and phenolic antioxidants of Areca (Areca catechu L.) seeds. Int Conf Agric Biosyst Eng 2011;1-2:16-22.

17. Huang PL, Chi CW, Liu TY. Effects of Areca catechu L. containing procyanidins on cyclooxygenase-2 expression in vitro and in vivo. Food Chem Toxicol 2010;48(1):306-13.

18. Xing Z, Jiao W, Zhuang H, Li MW, Fu DH. Antioxidant and cytotoxic phenolic compounds of Areca nut (Areca catechu L.). Chem Res Chin Univ 2010;26(1):161-4.

19. Roy S, Choudhury MD, Paul SB. Antioxidant potential of rhiome of Alocasia decipiens schott. Asian J Pharm Clin Res 2013;6(2):120-2.

20. Ramamoorthy P, Bono A. Antioxidant activity, total phenolic, and flavonoid content of Morinda citrifolia fruit extracts from various extraction processes. Int J Environ Sci Technol 2007;2(1):70-80.

21. Zhang WM, Huang WY, Chen WX, Han L, Zhang HD. Optimalization of extraction conditions of Areca seed polyphenols and evaluation of their antioxidant activities. Molecules 2014;19:16416-27.

22. Kamiya Y, Ohshima T. The individual cell properties of oral squamous carcinoma and tumor suppressor gene mutation. Oral Sci Int 2005;2(2):104-17.

23. Okamura M, Shimada J, Sakagami H. Comparative analysis of cell death induction by cisplatin and 5-FU in human oral squamous and hepatocellular carcinoma cell lines. Anticancer Res 2008;28:253-60.

24. Boukamp P, Petrussevska RT, Breitkreutz D, Hornung J, Markham A, Fusenig NE. Normal keratinization in a spontaneously immortalized aneuploid human keratinocyte cell line. J Cell Biol 1988;106(3):761-71.

25. Dewoto HR. The developing of Indonesia traditional herbal medicines in to phytopharmaca. Maj Kedokt Indon 2007;57(7):205-11

26. Bhisey RA, Boucher BJ, Hsi-Chen TH, Gajalakshmi V, Gupta PC, et al. Monographs on the evaluation of carcinogenic risks to humans. Betel-Quid and Areca-Nut Chewing and Some areca-Nut Related Nitrosamines. Vol. 85. California: IARCS Monographs; 2004. p. 1-293.

27. Nagao T, Ikeda N, Warnakulasuriya S, Fukano H, Yuasa H, Yano M, et al. Serum antioxidant micronutrients and the risk of oral leukoplakia among Japanese. Oral Oncol 2000;36(5):466-70.

28. Carossa S, Pera P, Doglio P, Lombardo S, Colagrande P, Brussino L, et al. Oral nitric oxide during plaque deposition. Eur J Clin Invest 2001;31(10):876-9.

29. Nair U, Bartsch H, Nair J. Alert for an epidemic of oral cancer due to use of the betel quid substitutes gutkha and pan masala: A review of agents and causative mechanisms. Mutagenesis 2004;19(4):251-62.

30. Johnson NW, Jayasekara P, dan Amarasinghe HK. Squamous cell carcinoma and precursor lesions of the oral cavity: Epidemiology and aetiology. In: Periodontology. 2000. Vol. 57. Singapura: John Wiley and Sons; 2011.

31. Anttila A, Bhat RV, Bhond JA, Bhorgoff SJ, Bosch FX, Carlson GP, et al. Monographs on the evaluation of carcinogenic risks to humans. Some Traditional Herbal Medicines, Some Mycotoxins, Naphthalene and Styrene. Vol. 82. California: IARCS Monographs; 2002. p. 171-4.

32. Hannan A, Karan S, Chatterjee TP. A comparative study of in vitro antioxidant capacity of different extract of Areca seed collected from Areca catechu L plant grown in Assam. Int J Pharm Pharm 2012;4(2):420-7

33. Tharakan B, Dhanasekaran M, Manyam BV. Antioxidant and DNA protecting properties of anti-fatigue herb Trichopus zeylanicus. Phytother Res 2005;19(8):669-73.

34. Kong Y, Ma W, Liu X, Zu Y, Fu Y, Wu N, et al. Cytotoxic activity of curcumin towards CCRF-CEM leukemia cells and its effect on DNA damage. Molecules 2009;14(12):5328-38

35. Gibellini L, Pinti M, Nasi M, De Biasi S, Roat E, Bertoncelli L, et al. Interfering with ROS metabolism in cancer cells: The potential role of quercetin. Cancers (Basel) 2010;2(2):1288-311.

36. Sakano K, Kawanishi S. Metal-mediated DNA damage induced by curcumin in the presence of human cytochrome P450 isozymes. Arch Biochem Biophys 2002;405(2):223-30.

37. Gupta SC, Hevia D, Patchva S, Park B, Koh W, Aggarwal BB. Upsides and downsides of reactive oxygen species for cancer: The roles of reactive oxygen species in tumorigenesis, prevention, and therapy. Antioxid Redox Signal 2012;16(11):1295-322.

38. Dance-Barnes ST, Kock ND, Moore JE, Lin EY, Mosley LJ, D'gostino RB Jr, et al. Lung tumor promotion by curcumin. Carcinogenesis 2009;30(6):1016-23.

39. Berridge MV, Herst PM, Tan AS. Tetrazolium dyes as tools in cell biology: New insights into their cellular reduction. Biotechnol Annu Rev 2005;11:127-52

40. Amruthraj NJ, Raj JP, Saravanan S, Lebel A. In vitro studies on anticancer activity of capsaicinoids from Capsicum Chinese against human hepatocellular carcinoma cells. Int J Pharm Pharm Sci 2014:6(4):254-8

41. Barltrop J. 5-(3-carboxymethoxyphenyl)-2-(4,5-dimenthylthiazoly)3-(4-sulfophenyl)tetrazolium inner salt (MTS) and MTS analogs of 3-(4,5-dimethylthiazolyl)-2,5-diphenyltetrazolium bromide (MTT) reducing to purple water-soluble formazans as cell-viability indicators. Bioorg Med Chem Lett 1991;1:611-4.

42. Sakagami H, Kobayashi M, Chien $\mathrm{CH}$, Kanegae H, Kawase M. Selective toxicity and type of cell death induced by various natural and synthetic compounds in oral squamous cell carcinoma. In Vivo 2007;21(2):311-20. 